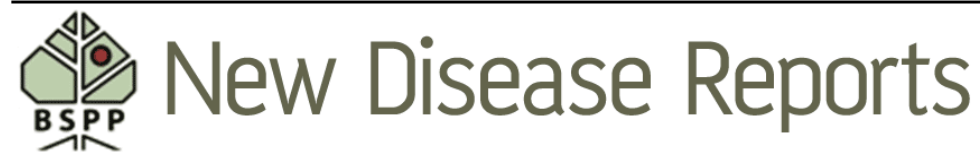

\title{
First report of Pseudocercospora angolensis causing leaf and fruit spot of Citrus in Sierra Leone
}

\author{
R. Harling ${ }^{1}$, I.M.O. Shamie ${ }^{2}$, S.S. Sesay ${ }^{3}$, A.B. Kamara ${ }^{3}$, R. Reeder ${ }^{1}$, E. Boa ${ }^{1}$ and P. Kelly ${ }^{1}$ \\ ${ }^{1}$ Global Plant Clinic, CABI-Europe, Egham, Surrey TW20 9TY, UK ; ${ }^{2}$ Ministry of Agriculture, Forestry and Food Security, \\ Youyi Building, West Wing, Freetown, Sierra Leone ; ${ }^{3}$ Ministry of Agriculture, Forestry and Food Security, Kabala, Northern \\ Province, Sierra Leone
}

*E-mail: rob.harling@yahoo.co.uk

Received: 12 Feb 2010. Published: 01 Jul 2010. Keywords: Phaeoramularia angolensis, Cercospora angolensis, cercosporiose

\begin{abstract}
In 2006, citrus fruit and leaves affected by dark brown lesions were noticed in orchards around Makeni in central Sierra Leone. The problem was considered widespread in the area by officers of the local station of the Ministry of Agriculture Forestry and Food Security (MAFFS).In 2008, a similar problem, also widespread in the area, was seen around Kabala, Koinadugu District in Northern Province, in the northeast of the country and close to the border with Guinea. Symptoms seen on mature fruits of mandarins (Citrus reticulata), the most common citrus type grown in Sierra Leone, were circular brown raised corky lesions $(5-30 \mathrm{~mm}$ diameter) which were thickened and resinous, most with cracked centres (Fig. 1). Affected mature mandarin fruits (cv. unknown) were sampled in April 2008 for diagnosis, from an orchard on Kamadugu Sokhura Road, Kabala. Isolations made from lesions on these fruits consistently revealed a fungus identified by morphological characteristics as Pseudocercospora angolensis (Pretorius et al., 2003). One isolate was deposited at the CABI Genetic Resource Collection (Accession No. IMI 396514). The symptoms on citrus are well documented (Smith et al., 1997; CABI 2009 and references therein) and were consistent with infection by this pathogen. The fungus was until recently called Phaeoramularia angolensis, but assigned to the genus Pseudocercospora following molecular and morphological re-examination (Pretorius et al., 2003).
\end{abstract}

$P$. angolensis causes an important disease of citrus in a number of countries in the humid tropics of Africa; all species of citrus appear to be susceptible (CABI, 2009).Lesions of citrus fruit spot are restricted to the skin of the fruit and do not cause rotting per se, although the cracking of the skin within the lesion can allow entry of secondary rotting microorganisms.The most important effects of the disease are the premature abscission of young fruit and leaves and the development of fruit lesions which render the fruit unmarketable. Growers reported many of the fruits lying unripened on the ground:most of the citrus trees in Kabala were affected with an estimated yield loss of more than $75 \%$.Yield losses of $50-100 \%$ from this disease are not uncommon in most disease-affected areas (CABI, 2009). P. angolensis is present in neighbouring Guinea to the north east (CABI, 2009); this is the first record of its occurrence in Sierra Leone. It is an A1 List quarantine pest in EPPO member countries ('Europe' in the wide sense). Not being present in the EPPO region it is therefore subject to quarantine restrictions (EPPO, 2009).

\section{References}

CABI, 2009. Crop Protection Compendium. [www.cabi.org/compendia/cpc/].

EPPO, 2009. EPPO A1 List of pests recommended for regulation as quarantine pests (Version 2009-09)

[http://www.eppo.org/QUARANTINE/listA1.htm].

Pretorius MC, Crous PW, Groenewald JZ, Braun U, 2003. Phylogeny of some cercosporoid fungi from Citrus. Sydowia 55, 286-305.

Smith IM, McNamara DG, Scott PR, Holderness M, eds, 1997. Quarantine Pests for Europe, 2nd edition. UK: CABI, Wallingford.

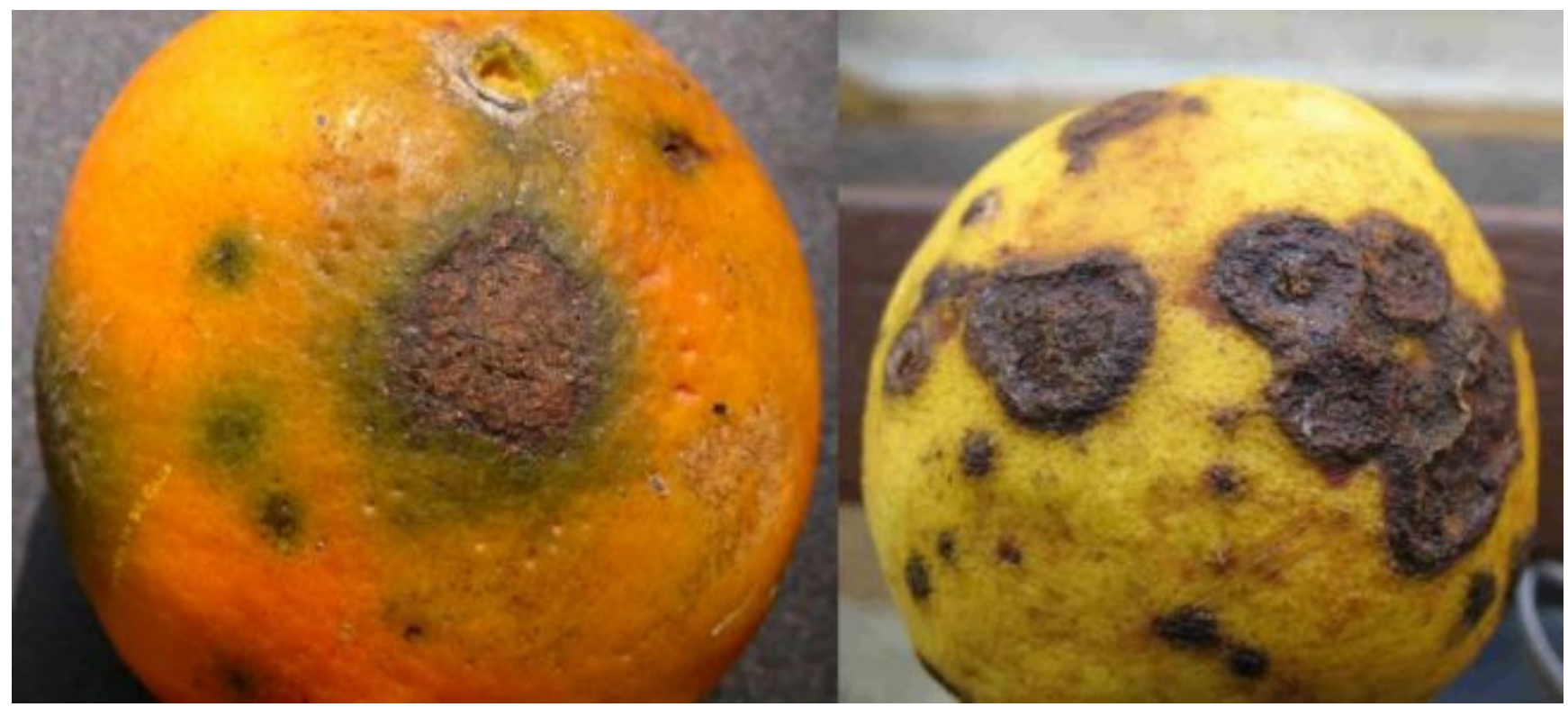

Figure 1

To cite this report: Harling R, Shamie IMO, Sesay SS, Kamara AB, Reeder R, Boa E, Kelly P, 2010. First report of Pseudocercospora angolensis causing leaf and fruit spot of Citrus in Sierra Leone. New Disease Reports 22, 1. [doi:10.5197/j.2044-0588.2010.022.001] (c) 2010 The Authors

This report was published on-line at www.ndrs.org.uk where high quality versions of the figures can be found. 